DOI: $10.2478 /$ ausfm-2020-0009

\title{
The Representation of Women and Female Mobility in Hungarian Films between 1931 and 1944
}

\author{
Györgyi Vajdovich \\ Eötvös Loránd University (Budapest, Hungary) \\ E-mail: vajdovich.gyorgyi@btk.elte.hu
}

\begin{abstract}
Györgyi Vajdovich's article aims to describe the representation of female roles in Hungarian feature films of the period 1931 to 1944. The study is based on the analysis of the database that was created within the framework of the research project The Social History of Hungarian Cinema. Concentrating on the representation of female protagonists, this article first analyses the presence and prevalence of female figures in all Hungarian sound films (up until 2015). Then it narrows the scope of analysis to films produced between 1931 and 1944, and describes the typical professions and social and financial positions of female protagonists, as compared to those of male protagonists. The second half of the text examines the representation of female upward mobility in comedies - showing that according to the popular myths of the era, female upward mobility is principally realized through good marriage, with the narratives of the films rarely presenting the professional success of female protagonists and their possibilities of emancipation. Analysing the narrative patterns and gender roles in the films of the time, the text concludes that the narratives of female ascension, which mostly took form in comedies, reflected the desire of middle-class people to transgress the social and financial boundaries in society. As such, the films served to maintain and strengthen the patriarchal order of the era. ${ }^{1}$
\end{abstract}

Keywords: history of Hungarian cinema, representation of women, female roles and occupations, social mobility, statistical data analysis.

The first period of the sound era in Hungarian film history between 1931 and 1945 was a very productive period, where 354 films were produced, film productions were almost continuously growing in number, and Hungary became the third biggest producer in Europe at the beginning of the 1940s (Sándor 1997, 137-138). In contrast

1 This paper was supported by the Hungarian National Research, Development and Innovation Office (number of Agreement: 116708). 
to the period after 1949, the film industry of this era was essentially a self-financed, market-based industry where private investors and companies produced films with minimal state support. Although the Hungarian film industry was controlled by the state, it predominantly aimed to meet the demands of the market, therefore we can surmise that the prevalent themes, motifs or narrative patterns satisfied the expectations of the contemporary public. The specific influence of the state can be traced in the controlling regulations: like in the institution of state censorship exercised after the production but before the release of the film (introduced in 1920, which prohibited and regulated the representation of certain motifs), and later also in pre-production (introduced in 1939, controlling the content of the script, the cast and the budget of the planned film); in the constitution of the censorship board; ${ }^{2}$ in the control over the studio facilities through which the state could give priority to preferred productions (Záhonyi-Ábel 2020, 116); and by providing production loans (Záhonyi-Ábel 2020, 115) and later premiums to selected works. The state also influenced film production with the enactment of anti-Jewish laws in the film industry $^{3}$ - which prompted a considerable change in the profile of filmmaking personnel from 1939, and tried to encourage the production of films with preferred ideological content. Therefore it is difficult to gauge to what extent state expectations and market demands determined production in that era. Film production was dominated by genre films: whereby $50 \%$ of the works were comedies, while the other $50 \%$ comprised six other genres, mostly melodramas. Films made specifically with artistic intentions were rare during this period. Even the often praised works by Paul Fejôs (director of Hungarian origin, who made two films of the era, Spring Shower [Tavaszi zápor, 1932] and The Water Decides [Ítél a Balaton, 1932]) and by István Szőts (director of Men in the Alps [Emberek a havason, 1941]), which are cast in a highly elaborate and artistic form, were unusual of the time - but were still essentially melodramatic pieces (Benke 2013, 29, 47). Although works

2 Márk Záhonyi-Ábel explains that members of the censorship board (National Motion Picture Examination Committee) were appointed by different institutions and social circles. Beside the different representatives of the state - like delegates of the Prime Minister's Office and of the Ministry of Home Affairs or other ministries -, representatives of different cultural or social circles (such as delegates from the film industry, members of the cultural or scientific elite, representatives of certain social institutions and different churches, etc.) also participated in the activity of the board, but generally the Ministry of Home Affairs appointed most of the leading officers, and the representatives of the different ministries had a decisive and continuously increasing share in the decisions (minimum $45 \%$, which increased to $80 \%$ by 1941) (ZáhonyiÁbel 2020, 214-296).

3 Through the establishment of the Hungarian Chamber of Film and Dramatic Arts, the regulations of the first anti-Jewish law entered into force in the film industry, which limited the number of Jewish persons working in the film industry at $20 \%$ and prevented them from working in upper positions. (Sándor 1997, 27-30; Gergely 2017, 201). 
conveying direct political messages were produced in small number, it seems that the often unpredictable application of censorship regulations and political pressure encouraged filmmakers to avoid risk and refrain from the representation of problematic topics and social criticism. Historians of Hungarian cinema generally consider that the films produced in this era were dominated by the expectations of the market and represented an idealized image of Hungary at the time - depicting more the dreams than the real life of the average viewers (Nemeskürty 1965, 105, 118; Gyertyán [1994], 21; Cunningham 2004, 41).

This study will examine the question of representation of female figures in Hungarian feature films between 1931 and 1944-comparing it to the social conditions of the time and exploring the narrative strategies that contributed to the creation of a so-called dream world. Starting from the statistical analysis of the database of Hungarian films that was created in the framework of the research project entitled The Social History of Hungarian Cinema, it will examine the narrative patterns and the social and gender roles related to women in the films of this era. It will first examine the proportion and prevalence of male and female protagonists, then the typical social and financial position of the figures and professions associated with the two genders, and finally it will focus on the possibilities of social and financial mobility in the case of female protagonists. ${ }^{4}$ Closer examination of female mobility in comedies compared to the results of certain surveys on social conditions of the time seems to prove the general statement of film history accounts that contemporary films represented an idealized image of contemporary Hungarian society. Detailed analysis shows that comedies that enact the upward mobility of female protagonists reflect the endeavour for social mobility of middle-class people in society at the time, while enforcing the traditional, patriarchal views on gender roles at the same time.

\section{Male and Female Protagonists in Hungarian Films}

The aim of our study is to assess the number and the importance of male and female protagonists in early Hungarian sound cinema, and the narrative patterns assigned to them. The differences in forms of financing, level of state control, and political and social circumstances resulted in the preference of different genres, topics and narrative patterns in the subsequent periods of Hungarian cinema, along with the varied representation of gender relations. Gender relations can be generally

4 The scope of this study is limited only to the analysis of data concerning the protagonists of the films. Although the database includes data of secondary figures as well, their enumeration was not exhaustive - therefore it would render statistical analysis unrealizable in that area. In the present study, data analyses are based on the version of the database as of 21. 09. 2019. 
described by the presence of male and female protagonists in films of different periods, so our examination first focused on the number of male and female protagonists, their relative proportions, and how these factors changed during the history of Hungarian sound cinema.

Figure 1 shows the respective number of male and female protagonists in relation to the number of films produced each year, and based on this data we can state that during the 80 plus years of Hungarian sound cinema male protagonists were more numerous across the films than female protagonists, except for three years (1941, 1980 and 2012) when the number of women in main roles slightly exceeded those of men. Therefore we can state that Hungarian cinema has preferred to depict male-centric stories, however, we can see considerable differences between certain periods. From the middle of the 1950s to the beginning of the 2000s the number of male protagonists exceeded the number of female ones considerably - where in most years their number was 1.5-2 times higher. This trend shows that during the decades when Hungarian cinema was dominated by author films and was financed and controlled by the state (being nationalized from 1949 until 1989), the malecentric narratives where female protagonists were present in smaller numbers (or were absent) or where women fulfilled only minor roles in the story, prevailed. Contrary to this trend, during the period between 1931 and 1944 (in fact on the basis of the data until 1948), the number of female protagonists correlated with (or were often equivalent to) the number of films, while the number of male protagonists was always slightly higher, but followed similar patterns. This correlation originates from the typical narratives and genres of the time. With the dominant genres of the time being comedy and melodrama, wherein the love story of a heterosexual couple created the core of the narrative, it meant that (at least) one male and one female protagonist was indispensable for the plots. This resulted in a relatively similar presence of both genders in the main roles of films produced in this era. A love plot was essential even to those works where the principal plotline was rooted in a different genre (for example crime stories, war films or spy films). Between 1931 and $1944,92 \%$ of films contained a love story, ${ }^{5}$ which generally occurred between the male and female protagonists. This did not mean that the representatives of the two genders had equal importance in the story, but contrary to later periods, during these years the heroine was almost always an indispensable partner to the hero.

$5 \quad$ From among the 354 films produced between 1931-1944, 327 contained a love plot. Love stories mostly took place between the protagonists; we can only find a few examples when the love story only constituted the plotline taking place between secondary figures. 
The slightly higher number of male protagonists is due to those narratives in which two heroes were competing for the heroine (examples of this type are provided by The Water Decides, Cobweb [Pókháló, Mária Balázs, 1936], Three Spinsters [Három sárkány, László Vajda, 1936], Sarajevo [Ákos Ráthonyi, 1940] or Closed Court [Zárt tárgyalás, Géza Radványi, 1940]); or narratives where beside the love plot another plotline was included which focused on a conflict between male characters (for example In Room 111 [A 111-es, István Székely, 1937], The Red Wallet [A piros bugyelláris, Béla Pásztor, 1938] or Unknown Opponent [Ismeretlen ellenfél, Endre Rodriguez, 1940]). Only the years 1942 and 1943 (during World War II) were exceptions to this trend, where the number of male protagonists far exceeded those of women (they were 10-30\% higher). During these years new types of narrative appeared beside the usual love comedies and love melodramas - they were war melodramas focusing on groups of male soldiers (for example Message from the Volga Shore [Üzenet a Volgapartról, Alfréd Deésy, 1942], Brothers-in-arms [Bajtársak, Ágoston Pacséry, 1942]), Hungarian Eagles [Magyar sasok, István László, 1943], and Storm Brigade [Viharbrigád, István Lázár, 1943]); works containing a crime story, a spy story or thriller elements (e.g. Guarding Post in the Outskirts [Külvárosi órszoba, Dezső Ákos Hamza, 1942], Sabotage [Szabotázs, Emil Martonffy, 1942], and A Machine Has Not Returned [Egy gép nem tért vissza, Ágoston Pacséry, 1943]); or the so-called problem films of right-wing ideology focusing on male peasant figures (e.g. The Thirtieth [A harmincadik, László Cserépy, 1942] and Your Loving Son, Peter [Szeretó fia, Péter, Bánky Viktor, 1942]. Therefore, we can state that the moderate correlation of the numbers of male and female protagonists is largely due to the dominance of love stories in Hungarian sound films before 1945. However, this type of narrative was never absent from the films produced in later decades, but became less prevalent - and the films that depicted it were fewer in number. Figure 1 seems to indicate that a pattern similar to the years 1931-44 reappeared after 2012. It would require further examination to establish whether this trend persisted after 2015, but we can state that these years were marked by the return of love stories - this time mostly in the form of contemporary romantic comedies.

\section{Typical Social and Financial Positions}

In order to be able to assess the idealization of the image created of society at the time, an analysis of the different social strata and their financial positions might be a useful indication. The database created in the framework of the research project includes data about different characteristics of the figures, therefore it enables 
the analysis of the prevalence of certain social groups and financial positions in relation to male and female protagonists. We have to note that the analysis covered the entirety of the feature films between 1931 and 1944, and therefore also included the pieces taking place in earlier historical periods or in foreign lands. This analysis does not exclude such works as there is the supposition that even these films reflected the values and ideals of Hungarian society at the time. A large proportion of non-contemporary plots were adapted from literary works which leaned on the popularity of the adapted pieces among readers - and plots taking place predominantly outside Hungary only constitute 9\% of the examined corpus, with more than half of them enacting stories of Hungarian characters abroad.

Analysis of the social strata of film protagonists shows that the representation of middle-class characters is dominant in the case of both male and female protagonists in all the periods of Hungarian sound cinema. However, films produced before 1945 [Figs. 2-3] depicted a more hierarchical society than those produced in the following eras, in accordance with the more hierarchical structure of Hungarian society of the time. Although middle-class figures represent the highest numbers both in the case of men and women, upper-middle-class and upper-class protagonists also constitute a considerable proportion throughout this period. Concerning the structure of society and the relative proportion of different strata, no significant differences can be traced between male and female protagonists. However, main figures belonging to the lower stratum of society, such as workers, peasants and lower ranking employees of businesses or the service industry who do not possess business property are represented in small numbers, creating the illusion that these circles represented only a small segment of society. Comparing this distribution of social strata to the actual social conditions of the time we can state that the dominant tendency in cinematic representation was to overrepresent upper-class groups and underrepresent lower-class groups of society. Lower-class figures only constituted $12-13 \%$ percent of the protagonists, which is in stark contrast to statistics that show that these groups made up more than $50 \%$ of the population of Hungary during this era (Kövér and Gyáni 2006, 205). In contrast to that, members of elite groups (such as rich aristocrats, landowners, and owners or managers of banks and factories) provided $15 \%$ of the protagonists, while their actual proportion in society was less than $0.5 \%$ of the population (Vajdovich 2018, 25). This tendency in representation created an image of Hungarian society where upper-class circles gained greater importance than their proportion in numbers, with their role in society becoming overrated. This seems to suggest that representation of upper-class groups reflected their power and dominance in contemporary Hungarian economy and political 
life, rather than their numbers. The prevalence of middle-class figures in film plots might be explained by the fact that most of the filmmakers and financers belonged to that group, and the majority of the cinema-going public also comprised loweror middle-class viewers (Nemeskürty 1965, 101-102), so we can suppose that this tendency fulfilled the expectations of the viewers (Nemeskürty 1983, 413, 417).

If we examine the financial position of male and female protagonists, we can state that it largely correlates with their social status. Protagonists with an average financial position dominated Hungarian sound film production until 2015, but the distribution of different financial positions of main figures in the films before 1945 reflects a more hierarchical society. No considerable differences can be observed in this dimension between male and female protagonists [Figs. 4-5], which is in contrast to later periods of Hungarian film history - where their relative positions showed a greater disparity.

However, the distribution of financial positions in these films does not completely correlate with that of the social strata. It would be logical to suppose that lower social status correlates with poverty, middle-class status with an average financial position, upper-middle-class position with considerable prosperity and upperclass position with great wealth, but statistical analysis of the characteristics of the figures show that a considerable proportion of middle-class protagonists are poor. Films of the era reflect an image of Hungarian society in which middle-class people lived in bad conditions and their financial position did not enable them to live the way of life traditionally associated with their level in society. This tendency in representation reflects an important phenomenon of society at the time: "the declassing of middle-class families in large numbers" (Kövér and Gyáni 2006, 162; Romsics 2010,128). It is also apparent that protagonists living in extreme poverty are rarely presented in films of the era, and we hardly see main figures with no abode or basic problems of subsistence. Most probably images of extreme poverty were largely absent because the representation of this subject would have led to social criticism - which was unwelcome in the film industry during this period. Although censorship regulations of the time did not forbid social criticism in films - and only excluded the disrespectful depictions of representatives of the state, of armed forces and Hungarian authorities, etc. -, decisions of the censorship board indicate a political pressure to avoid such topics. ${ }^{6}$ This distorted representation

6 A typical example is that authorities wanted to omit the scenes showing extreme poverty from the print of Men in the Alps that was sent to the Venice Film Festival in 1942, because "they shed negative light on the country" (Fazekas and Pintér 1998, 74). László Ranódy’s project entitled Abyss was refused a shooting permit because it intended to present the antagonism between the poor and the rich (Nemeskürty 1983, 579). Márk Záhonyi-Ábel also lists several examples from 
of society seems to support the statement of film historians considering films of this era as escapist. Although $77 \%$ of the films took place in contemporary times and $91 \%$ of them were mainly set in Hungarian locations, ${ }^{7}$ these works were not intended to give an authentic representation of contemporary Hungarian society. The focus on love conflicts, the almost complete dominance of happy endings, the ignorance of lower-class or very poor people and their problems all contribute to an idealized image of society at the time.

\section{Occupations of Male and Female Protagonists}

The professions associated with the main figures indicate the gender roles associated with men and women in contemporary society, and their comparison to the actual social circumstances reveal the highly conservative point of view of the filmmakers. Analysis of the data about protagonists shows that in contrast to the relatively similar distribution of social and financial positions of male and female figures, the distribution of typical occupations differs considerably.

If we examine the typical occupations of male and female protagonists [Figs. 6-7], we can only find two categories which are characteristic of both groups. The most frequent occupation for both genders is the category of dependent child, which basically marks a way of life without occupation when the young adult, but still unmarried, member of the family has no personal income and is supported by his/her family. This position means that the child is financially dependent on, and also subordinate to an elder member of the family - which is generally the father. ${ }^{8}$ This subordinate position is more frequent in the case of female protagonists, where almost one third of them (32\%) were dependent children, whereas less than one fifth of the male protagonists (18\%) were in an equivalent position. The other common occupation is artist, which seems to represent the very opposite position. Although being an artist did not always mean a source of income (upper-middle-class or middle-class figures often worked as an artist not for a living, but as a vocation),

the decisions of the censorship board, where scenes had to be omitted from a film or the licence of export was refused for films because they showed the problematic phenomena of Hungarian society or would have shed negative light on Hungary abroad (Záhonyi-Ábel 2020, 376-386).

7 For the calculation of these percentages, films where there was no information regarding the time or place of the plot were omitted. From 354 films of the era, there were around 30 films where there was no detailed information available (these are lost or highly deteriorated films).

8 A special characteristic of this era is that children or adolescents hardly appear among dependent children. This category mostly includes young adults or students before graduation, close to adult age. The reason can be the filmmakers' strong interest in love stories ending in marriage, and as such dependent children were interesting as potential partners to be married in the near future. 
but it was a kind of symbol of an unconventional way of life which was free of constraints and family obligations. It may be indicative of the level of freedom in the case of men and women that this occupation can only be found within $5 \%$ of the female protagonists, but $11 \%$ of the male ones.

The second most frequent occupation for female protagonists is housewife or female relative, which can be found within $15 \%$ of the heroines - followed by entertainment industry worker (7\%), service industry employee (6\%), office clerks and secretaries $(5 \%)$ and the above mentioned artists $(5 \%)$. On the contrary, in the case of male protagonists the second most frequent occupation is landowner, which has the same incidence as artist (they are both at 11\%). These are followed by such classical professions as engineer ( $9 \%)$, soldier or policeman ( $8 \%$ combined), and owner or manager of a factory or a bank $(6 \%)$. The most frequent occupations associated with male and female protagonists in the films reflect the actual differences between the circumstances and spheres of activities of the two genders. Almost half of the heroines are represented in a passive, dependent position - they are not active, productive members of society and their activities are limited to the household and the family. In contrast to that, only less than one fifth of the male protagonists are dependent, non-active members of society, and the majority of them have a profession which indicates a position of power or provides creative satisfaction. These figures partly correlate with trends in contemporary Hungarian society, as according to the statistics in 1930 less than one third of the female population was employed - with the number of active women up to $40 \%$ only in Budapest (Nagy 1994, 159, 164). However, the representation of female occupations could also serve to reinforce traditional concepts of female roles, as during World War I a large number of women started to work and would have liked to remain active after the war years, but conservative forces of the 1920-30s strived to restore earlier conditions and to reserve paying positions for men, against the backdrop of increasing unemployment (Karády 1994, 179).

However, the patterns of occupation represented in film did not follow real life trends in the case of women. Although we only have access to data on female professions in Budapest during this era, those show that the two most frequent forms of employment for women in the capital were those of factory workers and of domestic workers (Gyáni 1983, 26-27), and other occupations such as secretaries and other professions requiring a higher level of education only appeared gradually. Hungarian films of the time hardly represented the two most typical female occupations as only $1.5 \%$ of female protagonists were domestic workers, and those of factory workers did not even amount to $1 \%$. Domestic workers often figured in 
films as side characters, where they were indispensable elements of middle-class and upper-class households and were supporting figures beside the heroines - mostly serving as a source of humour. But women working in factories were completely ignored by the film industry of the time, even though it was a typical phenomenon of big cities undergoing modernisation to have an increasing number of working women, and this profession provided a relatively safe income and independence for women and it helped their emancipation. Peasant women are also underrepresented in films between 1931 and 1945, where only $3 \%$ of the protagonists are agricultural workers; they are rarely represented during work, and in most cases they serve as a symbol of pure, uncorrupted country life and as the love of the hero (e.g. John, the Hero [János vitéz, Béla Gaál, 1938]; Doctor István Kovács [Dr. Kovács István, Viktor Bánky, 1941]; Your Loving Son, Peter). Another underrepresented profession in film was that of pedagogues - where only four female protagonists had this occupation, despite it being the most frequent profession among educated women at the time (these films are Help! I’m an Heiress! [Segítség, örököltem!, István Székely, 1937]; Magda is Expelled [Magdát kicsapják, László Vajda, 1937]; Princess of the Puszta [Pusztai királykisasszony, Béla Csepreghy; 1938]; Quicksand [Futóhomok, Alfréd Deésy, 1943]). This profession increased among women in growing numbers, where in the 1930s almost half of the school teachers were women (Kövér and Gyáni 2006, 181-182). This created a special territory of female emancipation as, in contrast to the general expectations of the time, schoolmistresses often continued working after marriage, and sometimes even after having children (Kövér and Gyáni 2006, 182). But the films ignored the problem of the reconciliation of family and work, they rarely depicted their heroines at work, and they suggested that schoolmistresses would abandon their work after getting married at the end of the story.

Therefore we can state that the representation of male and female occupations contributed to the creation of an idealized image of society by overshadowing working and peasant women and expelling domestic workers to second- or thirdgrade roles in the film plots. The films also helped to reinforce traditional gender roles and restore a patriarchal order that was more accepted before World War I by representing female protagonists often in passive roles in a domestic sphere of activity, and avoiding the representation of occupations which offered the possibility of female emancipation. 


\section{The Representation of Male and Female Mobility}

The data on the details of the characters within the films provides the opportunity to examine the trajectories of mobility for both the male and female protagonists; as the database registers such changes in character attributes as social and financial ascension and decline, professional success, character development and moral decline, etc. Among these factors, social ascension and decline and financial ascension and decline are the characteristics which contribute to the representation of the social circumstances of the protagonists. We have to note that these concepts of mobility are not wholly aligned to their equivalent sociological terms, rather they describe the narrative attributes of the figures as expressed through their shift in state between the starting and closing points of the plot. Figures 8 and 9 show the prevailing trajectories of male and female protagonists in the films made between 1930 and 1944. In contrast to the typical social and financial positions, it is apparent at first sight that the films express different trajectories for male and female protagonists.

In the case of male protagonists the most common trajectory was financial ascension. We can note in the case of both sexes that the trajectories were more variable between 1931 and 1935 - this is partly due to the low number of films, but also to the experimentation in the first years of the sound era, as films had more varied topics and genres before 1935 than they did later on. ${ }^{9}$ The dominant pattern for male heroes was financial ascension, which was characteristic of $16-30 \%$ of male protagonists after 1935. Social ascension, however, was present with a much smaller percentage of male protagonists, at only $5-16 \%$ of the heroes. The social and financial decline of men was not a preferred topic in the films of the era as financial decline was only typical of $3-11 \%$ of male protagonists, and social decline did not exceed $5 \%$ (with the exception of the year 1944). However, the dominant narrative was where the social and financial position of the male protagonist did not change during the course of the plot, which was evident with almost one third (29\%) of the heroes. This means that films depicted a rather rigid society that provided only a limited chance of ascension for men; and where it did occur, it could mostly be realized in terms of financial position only, and not social. Bearing in mind that the majority of protagonists were middle-class figures, this tendency in representation reflected the rigidity of the contemporary Hungarian society, where trajectories of

9 Balogh and Király call the period 1931-36 "the period of the elaboration of Hungarian film style, the formation of the system of genres and stars" (Balogh and Király 2000, 61). Another study describes the experimentation inside the comedy genre before 1934 (Vajdovich 2014, 8-10). 
upward mobility were mostly closed for middle-class people. ${ }^{10}$ The films consider male positions to be relatively stable, with only a small chance of downward mobility, and even in the case of decline, they consider financial downfall more probable than a social one. Earlier studies demonstrated that this tendency in the representation of male protagonists was idealistic, as social and financial decline was a considerable problem in society at that time, both in the case of middle-class and elite groups (Lakatos 2018, 14-17; Vajdovich 2018, 28).

In the case of female protagonists, the films express a much more favourable trend in mobility as trajectories of both social and financial ascension were more open to them, and their chances of upward mobility seemed to be higher than those of men. Trajectories of financial ascension were typical of 9-39\% of female protagonists after 1935 , and social ascension of $13-37 \%$. Decline is much less prevalent among female protagonists than among men. It was not even portrayed before 1935, and it remained at a low level throughout the period - where social decline did not exceed $6 \%$, and financial decline did not exceed $7 \%$. However, the proportion of heroines whose status did not change was higher than those of heroes ( $5 \%$ higher during the whole era).

The comparison of the possible trajectories between the two sexes seems to suggest that women had more chances of upward mobility and that their trajectories were more varied: as social ascension was also open to them, in contrast to the circumstances of men. However, the following analysis will show that this impression is false in the sense that a greater chance of mobility did not bring forth greater freedom or range of possibilities for female figures. In the following we will examine what kind of trajectories of upward mobility were represented in the case of female protagonists, and the motives and the narrative patterns that underpinned them.

\section{Narratives of Female Ascension}

Gabriella Lakatos examined the narratives of ascension (or as she called them, success narratives) in films between 1931 and 1944 and she arrived at the conclusion that, taking into account both the protagonists and the important side characters, stories of ascension are present in $52 \%$ of the works (Lakatos 2018, 12). In contrast to that, narratives of social or financial decline are present in less than one fifth of the films, so it can be concluded that narratives of ascension make up one of the dominant topics in the era. Lakatos investigated the origins of ascension in comedies, and she

10 According to Ignác Romsics, trajectories of upward mobility were mostly open for workers or peasants and merchants or craftsmen. But it was rather difficult for representatives of the lowermiddle class to get access to the circles of upper-middle class, and it was practically impossible to enter the elite circle of great land owners and rich bourgeois (Romsics 2010, 134-135). 
stated that the rise in social or financial status is due to the talent or competence of the figure in only a small number of cases - whereas it is more typical that protagonists can rise as a result of favourable marriage, legacy, the help of relatives, some kind of disguise, or sheer luck. The most frequent reason for ascension in comedies is through good marriage (Lakatos 2018, 13), and the following analysis shows that this factor is even more dominant in the case of female protagonists.

A closer study of comedies featuring female ascension reveals that possibilities and spheres of ascension for heroines are very limited and are unvaried in type. The social or financial rise of the female protagonist appears in 70 comedies and concerns 72 heroines: which means $20 \%$ of the films and $18.5 \%$ of the female protagonists, therefore, it covers a rather expansive corpus. The most apparent characteristic of these comedies is that female protagonists are always present as part of a couple, sided by a male protagonist. This reveals the importance of the love motif, but also implies that female ascension is rarely independent from the presence of men. In fact, all these comedies close with a happy ending and $97 \%$ of them with a marriage - or the high probability of a marriage (in the remaining two films, the partners were married since the beginning of the film). These factors show that female ascension has a very limited scope, and in comedies it can never be realized outside marriage.

The majority of cases of female ascension in comedies concern middle-class protagonists. Upper- or upper-middle-class heroines only experience a raise in their status in eight films, and in half of them the typical narrative depicts a rich uppermiddle-class or a very rich bourgeois girl marrying a nobleman or high aristocrat, where their marriage facilitates the union of wealth and hereditary titles. The stories of impoverished upper- or upper-middle-class girls create interesting examples among these films because they express narratives of female emancipation. The heroine of the Old Villain (A vén gazember, Heinz Hille, 1932) is the daughter of a bankrupt baron who is in love with the grandson of their steward, an army officer of lowerclass origin. She refuses her family's request to marry a rich aristocrat and revolts against social expectations and etiquette in different ways, preferring the company of lower-class people to the traditional circles she moves in. At the end of the film she inherits great wealth from the steward, who stole it from her extravagant father, in order to save it for her. And in possession of valuable properties of her own, she is able to marry the partner she wishes to. This film does not only criticize the way of life of aristocrats, but provides an opportunity of autonomy for the young female character - which was rare in the films of this era. In two other films, Heart for Heart (Egy lány elindul, István Székely, 1937) and Keep On Smoking, Ladányi! (Te csak pipálj, Ladányi; Márton Keleti, 1938) the daughter of the impoverished upper- or 
upper-middle-class family revolts against family expectations for her to stay at home in passivity, and instead starts a business and helps her family gain back its earlier financial status. These films underscore female talent, capabilities and hard work: in contrast to the incompetence of the male members of the family. And although the films show that the businesses are built with the help of other members of the family, the fundamental professionalism stems from the young adult girl who is clashing with the social expectations of the time. And once these girls have restored the financial stability of the family, they can then choose their love partner in accordance with their own wishes. Both films also suggest that the heroine will not give up her job after marriage. However, it must be noted that these films provide exceptions to the general trend of representation among the films of this period.

In three quarters of the cases of female ascension, the heroine is a middle-class woman with an average or a bad financial status. In almost half of these stories of ascension, social and financial rise are both realized, and the most typical way of ascent is through good marriage. The most popular storyline of the comedies of the era is a love story where a young middle-class woman meets a rich man of a higher social level, and following several complications she ends up marrying him (István Nemeskürty calls this "the Car of Dreams story," as it was popularized by the film Car of Dreams [Meseautó, Béla Gaál, 1934], one of the biggest successes of the era) (Nemeskürty 1965, 118-124). This narrative pattern is present throughout the era, but is more dominant among female success stories between 1934 and 1938 than later. Typical examples of this storyline are the Car of Dreams, The New Relative ( $\mathrm{Az}$ új rokon, Béla Gaál, 1934), Keep Smiling! (Barátságos arcot kérek!, László Kardos, 1935), Address Unknown (Címzett ismeretlen, Béla Gaál, 1935), The Homely Girl (A csúnya lány, Béla Gaál, 1935), Lady Seeks a Room (Úrilány szobát keres, Béla Balogh, 1937), Affair of Honour (Lovagias ügy, István Székely, 1937), Friday Rose (Péntek Rézi, László Vajda, 1938), The Last Wereczkey (Az utolsó Wereczkey, Sándor Szlatinay, 1939), and One Bad Egg (Jómadár, Ákos Ráthonyi, 1943). This type of comedy suggests that a rise in financial or social status is only realizable for women in the society of the time through good marriage. The importance of financial stability is strongly emphasized in these stories, it being presented as the desired, ideal state of life for middle-class couples. Therefore, in those works where the male partner is not wealthier than the heroine, the couple must come into the possession of money in some way. In certain stories, one of the partners inherits land or property from some distant family member (e.g. in Help! I'm an Heiress!, and Dream Waltz [Álomkeringó, Félix Podmaniczky, 1942]), in which cases financial ascension is not due to the marriage, but takes place simultaneously with it. In some films the female 
protagonist comes into the possession of some money (e.g. Borrowed Husbands [Kölcsönkért férjek, Viktor Bánky, 1941] or Kádár vs. Kerekes [Kádár kontra Kerekes, Ákos Ráthonyi, 1941]), while in a few films the male protagonist gets into better financial status due to some lucky turn (e.g. Bachelor Flat to Let [Garszonlakás kiadó, Béla Balogh, 1939] or Left-Handed Angel [Balkezes angyal, Ákos Ráthonyi, 1940]). A common element of the different variations of comedy is that financial stability is a prerequisite to marriage - therefore either the male hero has to be rich, or the couple has to get into a better financial position prior to their wedding. In Bachelor Flat to Let this problem is verbalized when the heroine (a poor beautician) tries to convince her fiancé (a newly graduated doctor) to get married in spite of their poverty, but he is not willing to do so until he earns enough for both of them. The conflict between financial ascension and social decline is presented in only one film, The Sun Shines (Süt a nap, László Kalmár, 1938), where the middle-class heroine (the daughter of a village priest) gets married to a wealthier, but lower-class peasant after a lot of contemplation on the part of the family, who are reluctant to accept her social decline as the price for her future financial stability.

Stories of lower-class female protagonists present similar narrative patterns, with the small difference that for women of these social circles marriage with a middleclass man is considered a lucky turn. Consequently, in The Friend of the Minister (A miniszter barátja, Viktor Bánky, 1939) the poor manicurist is happy to marry the man she thought to be an upper-class figure, even when she realizes that he is only an engineer; in Friday Rose the penniless orphan girl wants to marry the school doctor even if he earns poorly; and in African Fiancé (Afrikai vólegény, István Balogh, 1944) marrying a petroleum engineer means considerable ascension for the poor employee of a beauty salon.

As a conclusion, we can state that narratives of female ascension in Hungarian comedies between 1931 and 1944 present good marriage as the fundamental mode of ascension. Good marriage primarily equates to the notion of financial stability, such that the man can be considered to be a good match where he can bear sufficient income for his wife and his future family, but it is even better if marriage helps the female partner also to ascend in social hierarchy. Only rich girls (generally heiresses of wealthy upper-middle-class families) can afford to ignore the financial aspect, but in those cases the family expects the heroine to use her wealth to enter the upper class by marriage. However, these films tend to present the narrative primarily as a love story, with financial considerations being secondary in the plot, where the poorer or lower-class female partner accidentally happens to fall in love with a male partner who is wealthier and/or in a higher social position than her. 
Narratives of female ascension of the era overshadow the professional success and career of women. In the films where the female protagonist has a good business idea, the success narrative is presented in a way that she cannot realize it on her own: she has a male partner in the business or her family, who takes part in the realization (e.g. Heart for Heart or Keep On Smoking, Ladányi!). In those cases where the female protagonist had a successful career prior to marriage, she has to renounce it after the wedding. Most of these stories present women working in the entertainment industry: actresses or singers who are able, or would be able to sustain themselves and be independent, emancipated women. But the love narratives position marriage over career, so these heroines opt equally for marriage either if they are well-earning artists at the peak of their career (e.g. The Wise Mother [Az okos mama, Emil Martonffy, 1935], Three Spinsters [Három sárkány, László Vajda, 1936], Old Waltz [Régi keringó, Viktor Bánky, 1941]), or if they have gained their first success and have the potential to become independent, self-sustaining women (e.g. The New Relative, Barbara in America [Borcsa Amerikában, Márton Keleti, 1938]). Unique examples are provided by The Last Wereczkey, where the heroine is the manager of a transport company and has a key role in the proper functioning of the company, and Leave It To Zsuzsi (Mai lányok, Béla Gaál, 1937), where the female protagonist learns to become a joiner and interior designer, and opens a furniture and decor store with her friends. In both these cases the female protagonist is presented as a successful business woman, but at the end of the story she chooses marriage, leaving her successful professional career behind without hesitation. And although her future husband will be able to sustain their family, she renounces the independence that is assured by her personal income.

Female initiative and creative problem solving can only operate effectively in one area in the films: that of the activities of finding one's match. Although the ideal woman of the era is supposed to be modest, shy and be passively waiting for the initiative of men, in half of the narratives of female ascension the female protagonist actively contributes to the formation or fulfilment of the love story. In certain films the heroine takes the initiative, and pretending to be a modest and conservative girl applies different strategies to entangle the potential husband-to-be (like in the story of Thanks for Knocking [Köszönöm, hogy elgázolt, Emil Martonffy, 1935], You Will Be My Husband! [Maga lesz a férjem, Béla Gaál, 1937], or Leave It To Zsuzsi). In other cases the female protagonist makes her partner jealous to compel him to confess his feelings and propose to her without delay (e.g. in The New Relative, Little Mary [Marika, Viktor Gertler, 1937], or Sweet Opponent [Édes ellenfél, Emil Martonffy, 1941]). In a few works the female protagonist fights for her 
legacy (The Last Wereczkey, Borrowed Husbands) or helps the male protagonist into a position of good income (The Chequered Coat [Pepita kabát, Emil Martonffy, 1940], or Heart for Heart) thus establishing the financial stability necessary for their wedding. These narratives suggest that women should utilize their talent and capacity not in the arena of work, but for seduction (so as to entice or advance a marriage proposal) or for creating situations where the financial conditions of the wedding can be ensured.

As a conclusion we can state that narratives of female ascension presented in comedies mostly enact the rise in social and/or financial position of middle-class women, who in several cases are in a bad or not very favourable financial situation. In contrast to the actual descriptions of social conditions of the time, we can conclude that the films created an idealized image of society as the stories suggested that social and financial rise is possible, while in real life these trajectories were generally closed for middle-class people. The pessimistic perspective in the films is expressed by the implication that women have more chance to rise than men, and they present marriage as the primary form of ascension, overshadowing professional success, talent or hard work. At the same time these cinematic narratives reinforced the traditional state of things, suggesting that women should not pursue a professional career after marriage, even if they are successful in their profession.

\section{Female Narratives Told by Men}

These conservative narratives prioritizing marriage always present an idealized image of such relationships. While in society at the time partners were selected and marriages occurred based on practical and financial considerations (with such considerations taking form in several films of the era), the films underscored the myth of love marriage that was predominant in popular culture. Although narratives of female ascension always present stories ending in a marriage to be beneficial for the female protagonist from a social and/or a financial point of view, they are primarily presented as the fulfilment of a love story - where these other gains are subsidiary advantages. The priority of (good) marriage is especially apparent in stories where there is a big age difference between the two partners (e.g. Iron Man [Márciusi mese, Emil Martonffy, 1934], Friday Rose, Biting Husband [A harapós férj, Márton Keleti, 1937], Orient Express [Orient Express, László Cserépy, 1943]) or where the male partner to be conquered is unpleasant and unattractive at the beginning (Help! I'm an Heiress!, Biting Husband, There are Exceptions [Tisztelet a kivételnek, Ákos Ráthonyi, 1936], Sweet Opponent). It can even happen that the 
female protagonist eventually marries another man that she wished for, if the new partner is wealthier or higher in position. In Iron Man the female protagonist pays a visit to the uncle of her love to convince him to give permission for their marriage, then ends up marrying the uncle, who is considerably wealthier and in a higher social position than the original fiancé, but also about twenty years older. There is No Accident (Nincsenek véletlenek, László Kalmár, 1938) presents an even more unusual love story about a newly married bride who spends her wedding night searching for a ring in order to convince her husband of her fidelity. During her search she meets a playful, kind young man (who happens to be rich and upper class), and by the morning she lets her new husband divorce her and accepts the marriage proposal of the other man that she met only a few hours earlier.

All comedies of this era celebrate the happy union of lovers, and most of them, especially narratives of female ascension, present these stories as the fulfilment of female desires. The emphasis on the supposed desires of women is particularly strong, as half of the narratives of female ascension have a female focus: they present the story from the female protagonist's point of view, and show the events of her life and her emotional changes - such that viewers identify with her. One quarter of these narratives operate with a double focus (alternating between the male and the female protagonist's point of view), and only one quarter of them express these trajectories through male eyes. As a result, a large proportion of the comedies of the era presented these conservative male-female relationships of patriarchal order as a reflection of the female psyche, and thereby repressed notions of female strivings for independence or emancipation.

As we examine this question we should not forget that popular myths of the time were created and presented mostly by men, and in the film industry they were almost exclusively created and presented by men. Out of the 354 Hungarian feature films made between 1931 and 1944 only two films were directed by women (Cobweb [Pókháló, Mária Balázs, 1936] and Light and Shadow [Fény és árnyék, Klára Tüdős, 1943]). Almost half of the scripts of the era were adapted from a contemporary or classical literary work: out of which only nine were adaptations of works by female authors. Other areas of culture were also dominated by men: for example according to statistics from 1930 only $3-4 \%$ of journalists were women, and only $8 \%$ of the authors enlisted in the encyclopedia of Hungarian writers were female (Papp and Sipos 2017, 65). This resulted in the depiction of women being dominated by male authors, and discourses at the time about the role of women were guided and controlled by men. Papp and Sipos cites different opinions about the role of women in society of the time, most of which idealized traditional female roles (Papp and 
Sipos 2017, 66-68). Typical views considered the vocation of a woman as being a wife and mother (Papp and Sipos 2017, 66), others declared that women would be unhappy if they could not join and serve a partner (Papp and Sipos 2017, 67). At the same time some of the encyclopaedias already mentioned feminists striving for emancipation (Papp and Sipos 2017, 69-71).

In reality, female emancipation tendencies appeared in several different areas of society at the time. The number of working women showed continuous growth (Nagy 1994, 158-162), just like the numbers of women who remained active in their profession after their wedding. Widows were present on the labour market even before the 1930s, but during this era more and more divorced women also started to work (Nagy 1994, 162-163). The economic segregation of men and women decreased, therefore an increasing number of women took positions in professions previously reserved for men (Nagy 1994, 164). Although both the proportion of educated women and the level of women's education were considerably lower than that of men during this era, more and more fields of higher education opened to female students (first teacher training, then humanities and medical universities, later engineering, and finally, at the end of the era, faculties of law) (Karády 1994, 185). Women suffered from disadvantages both in education and on the labour market (Nagy 1994, 164), which generated frustration among them and led them to strive for emancipation. At the same time large numbers of female workers who replaced the male workforce during World War I did not intend to give up their positions, and wished to remain active. But the rate of unemployment increased, and conservative groups favoured men in working positions, as they were perceived as the breadwinners of families. Therefore popular myths praising traditional male and female roles were not only supported by conservative Christian ideologies, but also by the prevailing economic necessities. These myths presented marriage as the absolute aim of female protagonists in the films and tried to convince female viewers to return to traditional female roles, to renounce work, and to accept the role of housewife.

Films of the era represented working women, but the representation of independent, self-sustaining women, mostly in upper positions in companies, is rarely completely positive. Women in leading positions tend to be depicted as incompetent, ridiculous figures or bad managers. The most typical example of this type is the leading figure of Miss President (Elnökkisasszony, Marton Endre, 1935) who inherits a big textile factory from her father, but she behaves childishly and is absolutely incompetent as a manager, so she must quickly get married so that the company can have a male president. The female protagonist of The 2000 Pengoes Man (Kétezer pengós férfi, László Cserépy, 1942) dresses in a manly way and directs the family company in 
a very strict manner - to prove herself as a president of the chemical factory; and the heroine of Hotel Sunrise (Hotel Kikelet, Béla Gaál, 1937) can only run her hotel successfully at the risk of ending her marriage, and eventually she has to relinquish the manager's position to her husband to save their marriage.

Women who are successful in their career are not taken seriously. The heroine of Seven Plum Trees (Hétszilvafa, Félix Podmaniczky, 1940) is a good manager of her father's factory and land, but everybody considers her as a young girl to whom they can marry; while the female protagonist in This Happened in Budapest (Ez történt Budapesten, Ákos D. Hamza, 1944) is a successful lawyer, whom we only see in traditional female roles such as organizing a dinner, receiving guests, taking care of a child, and enticing the male lead etc. Therefore if films included emancipated, independent women, these figures were mostly represented as incompetent or foolish, or the importance and success of their work was minimized.

The above examined cases of female ascension all belong to the group of comedies, therefore the happy ending - the union of the male and female protagonist at the end of the story - partly exists to fulfil the audience's expectations of the genre, which is partly an influence of Western models of film comedy. Genre specificities of romantic comedies expect the representation of the birth and development of the love relationship, and the union of the couple in the end, which in this era was equivalent to marriage. Melodramas often represented male-female relationships after the wedding, thus creating the opportunity to represent problems of marriage. But according to Attila Benke, they often ended with the restitution of traditional patriarchal order (Benke 2013). Stories of female ascension in melodramas mostly end in marriage, so even if they represent the problems of love relationships, or the tragic side of love, they also enforce the value and position of marriage (except for a few cases when one of the partners dies). Therefore, narratives of female ascension of this era, even if they include an independent, emancipated female protagonist, both in comedies and melodramas, envision female ascension via marriage or through some events linked to or happening parallel to the heroine's wedding, and do not consider professional success as a possible trajectory of ascension for women. 


\section{Conclusion}

Our examination of Hungarian feature films produced between 1931 and 1944, based on the database of films of the era, has shed light on certain aspects of the representation of female protagonists. It showed that a dominant proportion of female protagonists were of middle-class origin and in average or bad financial circumstances - reflecting the unfavourable social and economic trends having a negative effect on this social strata. Almost half of the heroines were portrayed as inactive women, who, lacking a personal income, were financially dependent on and subordinated to male members of their family. Even if Hungarian society of the time was rather rigid, films suggested that trajectories of social and financial ascension are more open for women than men, although they positioned marriage as the primary mode of ascension. Considering the fact that the majority of the filmmakers and the public also belonged to the middle class, we can suppose that the narratives of female ascension, which mostly took form in comedies, reflected the desire of middle-class people to transgress those social and financial boundaries which were generally closed for them. At the same time narratives of female ascension reinforced traditional views on the role of women in society, denying their success in business and work, emphasizing the primary importance of marriage, and suggesting that a professional career cannot be reconciled with the vocation of being a married woman and a mother. This trend in representation ignored those phenomena in society that opened up the way for female emancipation in education, in work or in wedded life. Therefore, films of the era strengthened the patriarchal order that was prevalent in society and conveyed a rather conservative image of Hungarian society at the time.

\section{References}

Balogh, Gyöngyi and Király Jenő. 2000. „Csak egy nap a világ...” A magyar film müfaj- és stílustörténete 1929-1936 ["The World is But a Day...” The History of Hungarian Film Genres and Styles 1929-1936]. Budapest: Magyar Filmintézet. Benke, Attila. 2013. Hazatérések. Házasság és család válsága az 1939-45 közötti családi melodrámákban [Homecomings. Crisis of Marriage and Family in Family Melodramas between 1939-45]. Metropolis vol. 17, no. 2: 28-49. http://www. metropolis.org.hu/hazateresek. Last accessed 20. 12. 2019.

Cunningham, John. 2004. Hungarian Cinema from Coffee House to Multiplex. London: Wallflower Press. 
Fazekas, Eszter and Pintér Judit. 1998. Szőts István. Metropolis vol. 2, no. 2 (Summer): 72-90. http://www.metropolis.org.hu/szots-istvan-2. Last accessed 20. 12. 2019.

Gergely, Gábor. 2017. Hungarian Film, 1929-1947. National Identity, Anti-Semitism and Popular Cinema. Amsterdam: Amsterdam University Press.

Gyertyán, Ervin. [1994]. Mit ér a film, ha magyar? [What are Films Worth - If They are Hungarian?]. [Budapest]: MTM Kommunikációs Kft and Mokép.

Karády, Viktor. 1994. A társadalmi egyenlőtlenségek Magyarországon a nők felsőbb iskoláztatásának korai fázisában [Social Inequalities in Hungary in the Early Phase of Female Higher Education]. In Férfiuralom. Írások nókról, férfiakról, feminizmusról [Male Dominance: Writings on Women, Men and Feminism], ed. Hadas Miklós, 176-195. Budapest: Replika kör.

Kövér, György and Gyáni Gábor. 2006. Magyarország társadalomtörténete a reformkortól a második világháborúig [Social History of Hungary from the Reform Age to World War II]. Budapest: Osiris. https://www.tankonyvtar.hu/hu/tartalom/ tamop425/2011_0001_520_magyarorszag_tarsadalomtortenete/adatok.html. Last accessed 15. 08. 2018.

Lakatos, Gabriella. 2018. „Aki dolgozik, az nem ér rá pénzt keresni.” Sikernarratívák a magyar vígjátékokban 1931 és 1944 között [“Those Who Work Have No Time to Earn Money:" Success Narratives in Hungarian Comedies between 1931 and 1944]. Metropolis vol. 22, no. 3: 10-23.

Nagy, Beáta. 1994. A nők keresőtevékenysége Budapesten a 20. század első felében [Earning Activities of Women in the First Half of the 20th Century in Budapest]. In Férfiuralom. Írások nókról, férfiakról, feminizmusról [Male Dominance: Writings on Women, Men and Feminism], ed. Hadas Miklós, 155-175. Budapest: Replika kör.

Nemeskürty, István. 1983. A képpé varázsolt idő: A magyar film története és helye az egyetemes kultúrában, párhuzamos kitekintéssel a világ filmmúvészetére [Time Conjured into Image: A History of Hungarian Cinema and Its Position in World Culture with a Glance on World Film History]. Budapest: Magvető Könyvkiadó.

Nemeskürty, István. 1965. A magyar film története (1912-1963) [Hungarian Film History (1912-1963)]. Budapest: Gondolat.

Papp, Barbara and Sipos Balázs. 2017: Modern, diplomás nô a Horthy-korban [Modern, Highly Educated Women in the Horthy Era]. Budapest: Napvilág Kiadó. Romsics, Ignác. 2010. Magyarország története a XX. században [A History of Hungary in the 20th Century], Budapest: Osiris Kiadó. https://www.tankonyvtar. hu/hu/tartalom/tamop425/2011_0001_520_magyarorszag_tortenete/index.html. Last accessed 05. 08. 2019. 
Sándor, Tibor. 1997. Örségváltás után: Zsidókérdés és filmpolitika 1938-1944 [After the Changing of the Guard: The Jewish Question and Film Policy, 1938-1944]. Budapest: Magyar Filmintézet.

Vajdovich, Györgyi. 2018. Grófok, bárók, gyártulajdonosok, bankigazgatók: Az elithez tartozó férfi hősök az 1931-1944 közötti magyar játékfilmekben [Counts, Barons, Factory Owners, Bank Managers: Upper-Class Male Heroes in Hungarian Films between 1931 and 1944]. Metropolis vol. 22, no. 3: 24-41.

Vajdovich, Györgyi. 2014. Vígjátékváltozatok az 1931-1944 közötti magyar filmben [Variants of Comedies in Hungarian Cinema between 1931-1944]. Metropolis vol. 18, no. 3: 8-22.

Záhonyi-Ábel, Márk. 2020. Filmcenzúra Magyarországon a Horthy-korszakban [Film Censorship in Hungary during the Horthy Era]. Unpublished PhD Dissertation, Budapest: ELTE University, Faculty of Humanities.

\section{List of Figures}

Figure 1. Number of male and female protagonists in relation to the number of films per year.

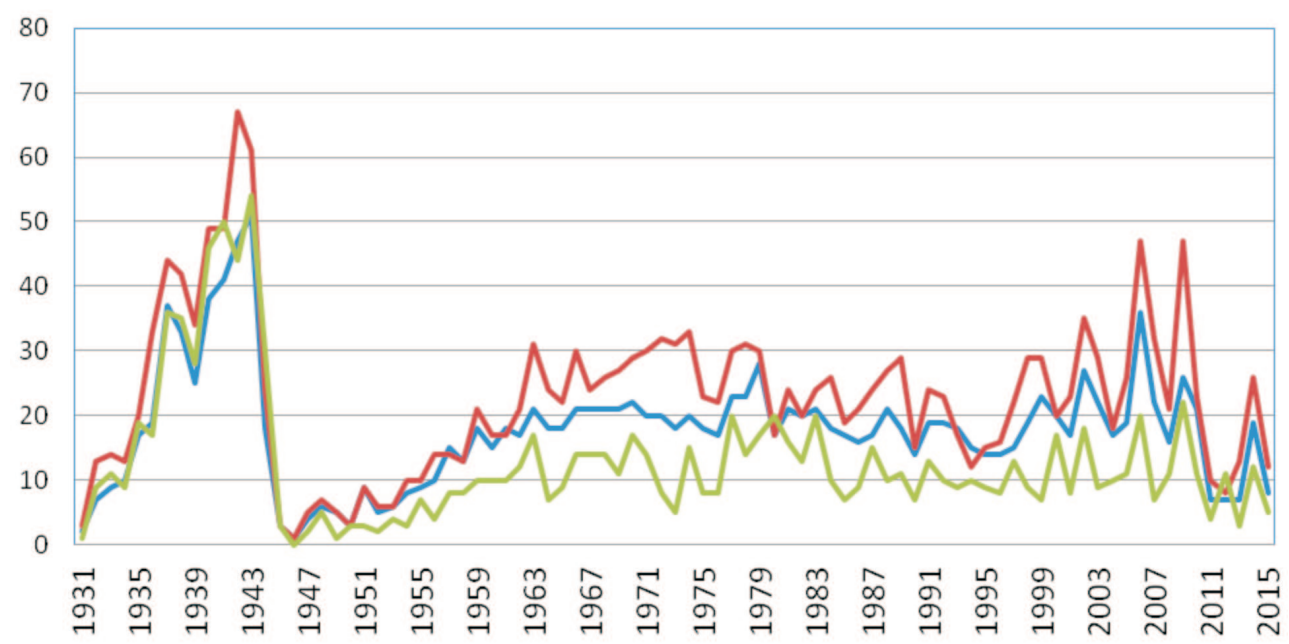

- No of films - No of male protagonists - No of female protagonists 
Figure 2. Distribution of male protagonists according to social strata (number per year).

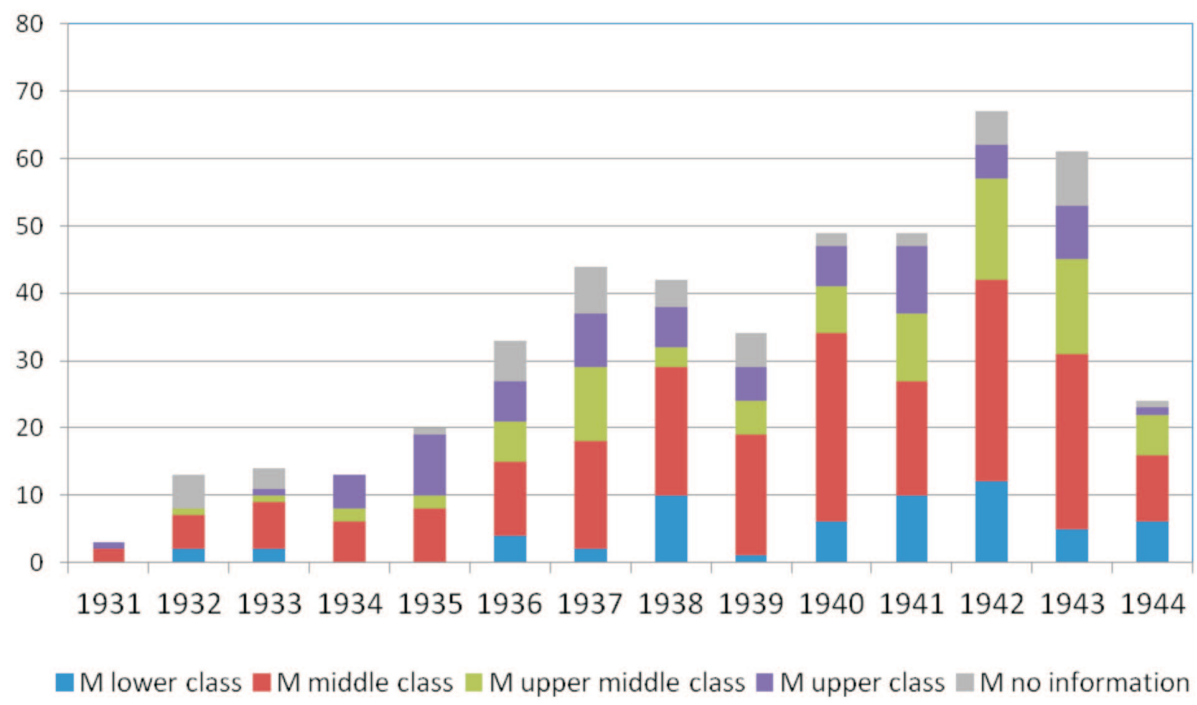

Figure 3. Distribution of female protagonists according to social strata (number per year).

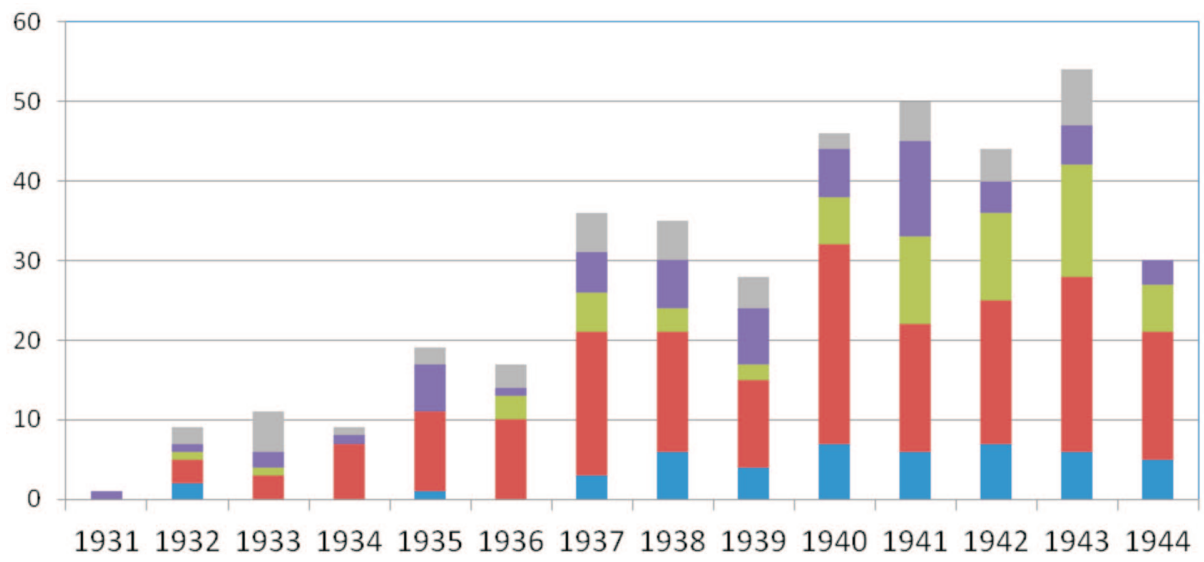

口 lower class $\square \mathrm{F}$ middle class $₫ \mathrm{~F}$ upper middle class $\square \mathrm{F}$ upper class $₫ \mathrm{~F}$ no information 
Figure 4. Distribution of male protagonists according to financial position (number per year).

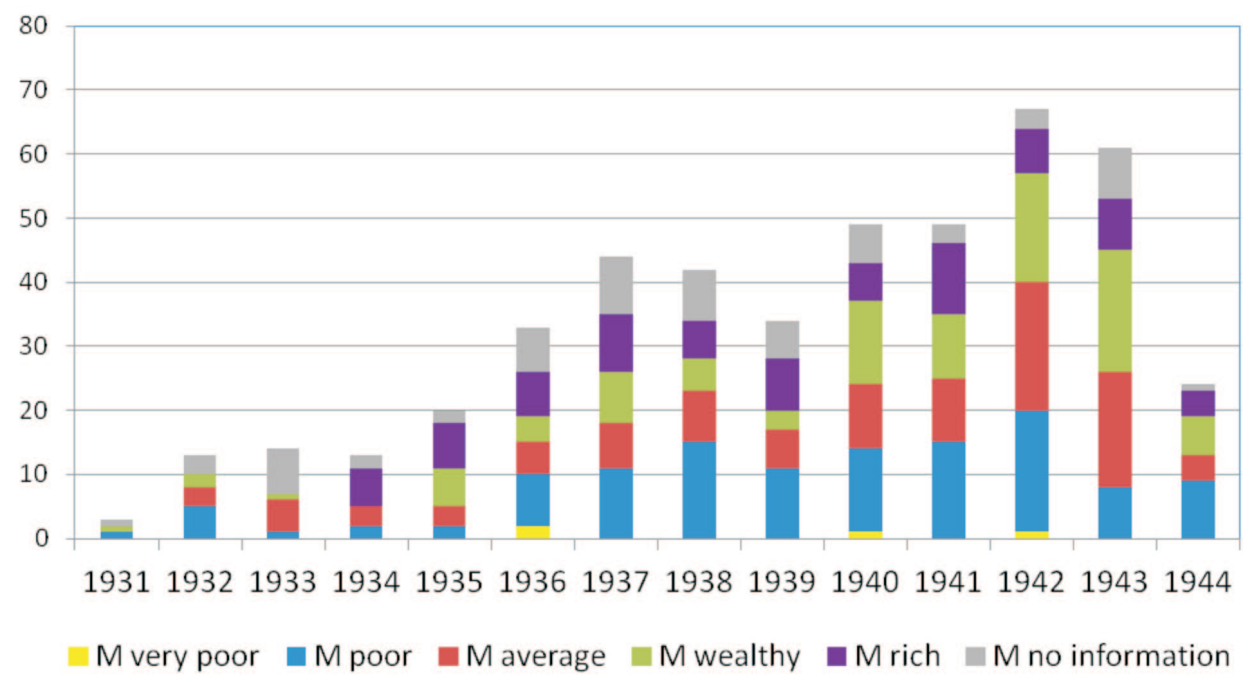

Figure 5. Distribution of female protagonists according to financial position (number per year).

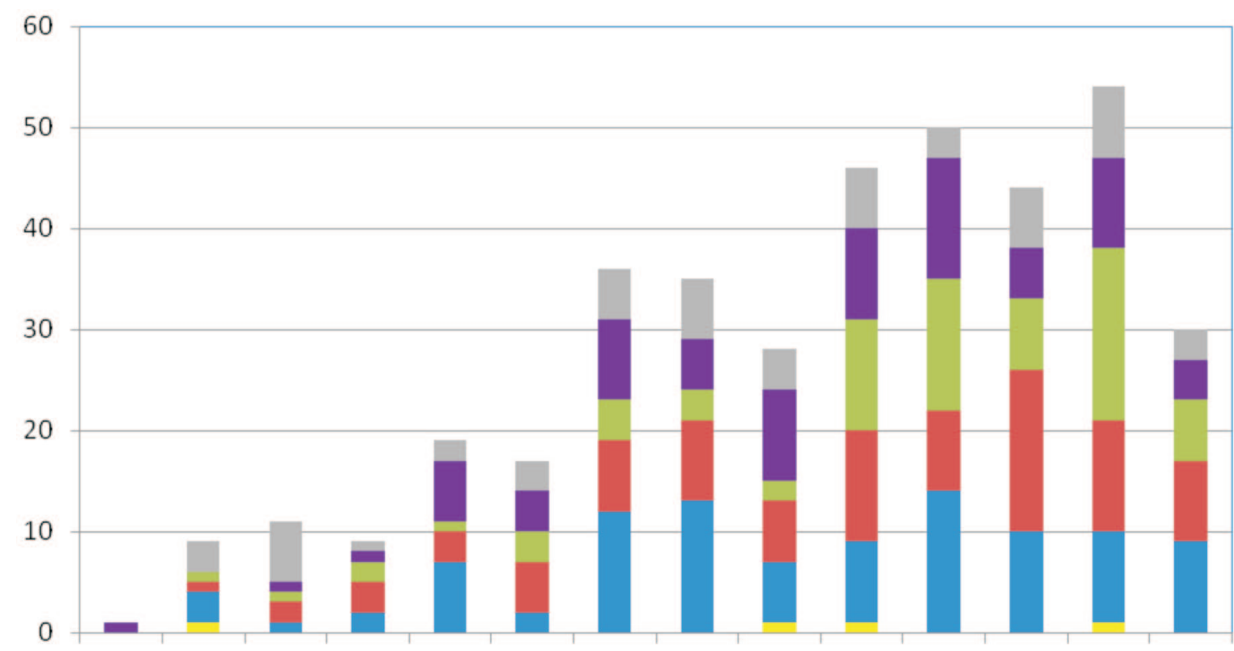

19311932193319341935193619371938193919401941194219431944

Fvery poor $\square$ F poor $\square$ Faverage $\square$ F wealthy $\square$ Frich $\square$ F no information 
Figure 6. Occupation of male protagonists (percentage of figures).

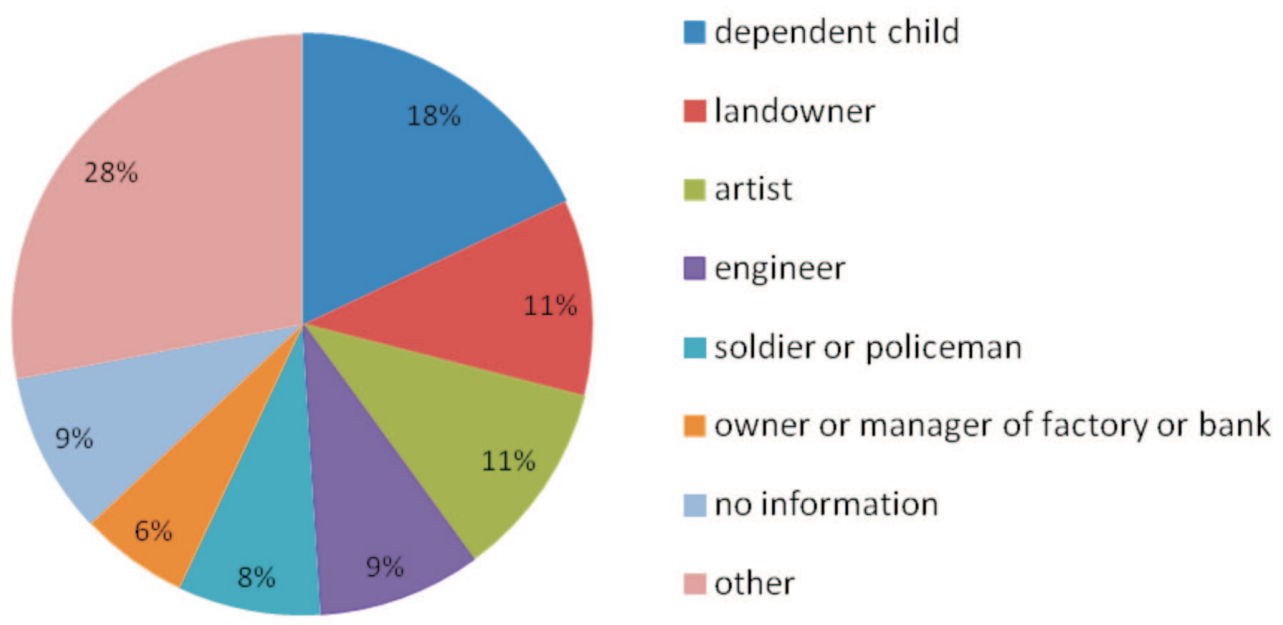

Figure 7. Occupation of female protagonists (percentage of figures).

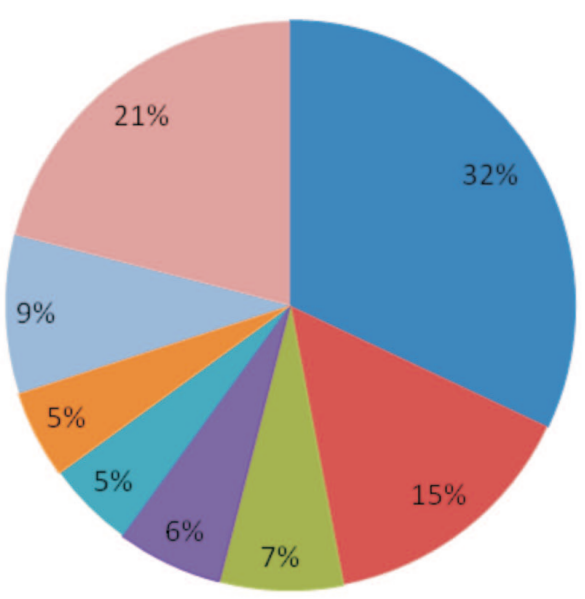

dependent child

housewife or female relative

entertainment industry worker

service industry employee

a office clerk

artist

no information

ather 
Figure 8. Social and financial mobility of male protagonists (percentage of male protagonists per year).

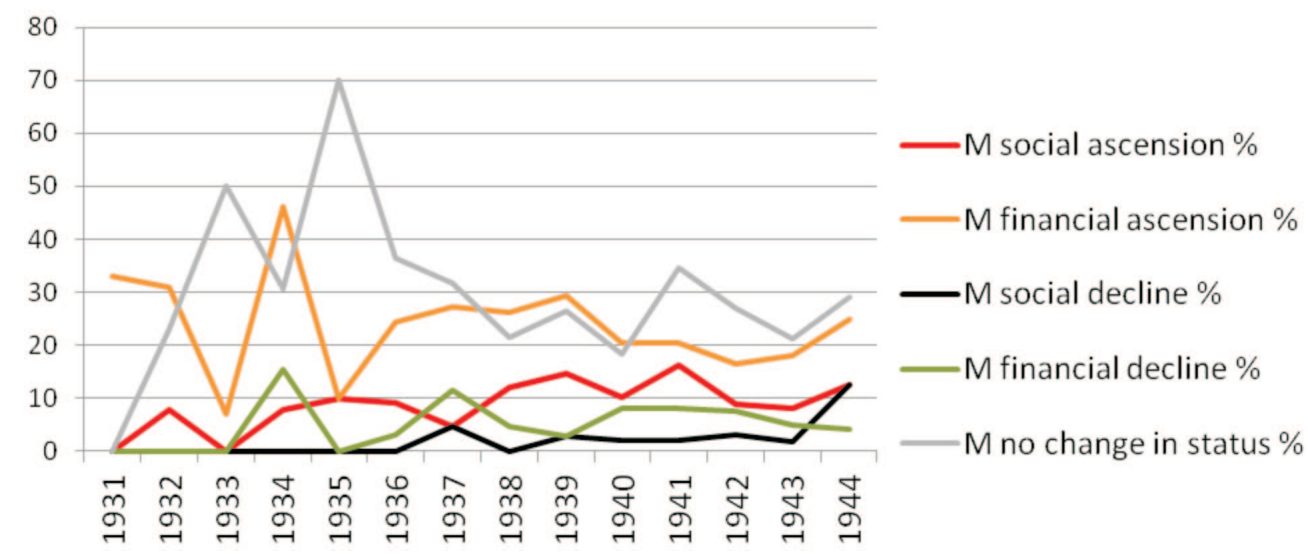

Figure 9. Social and financial mobility of female protagonists (percentage of female protagonists per year).

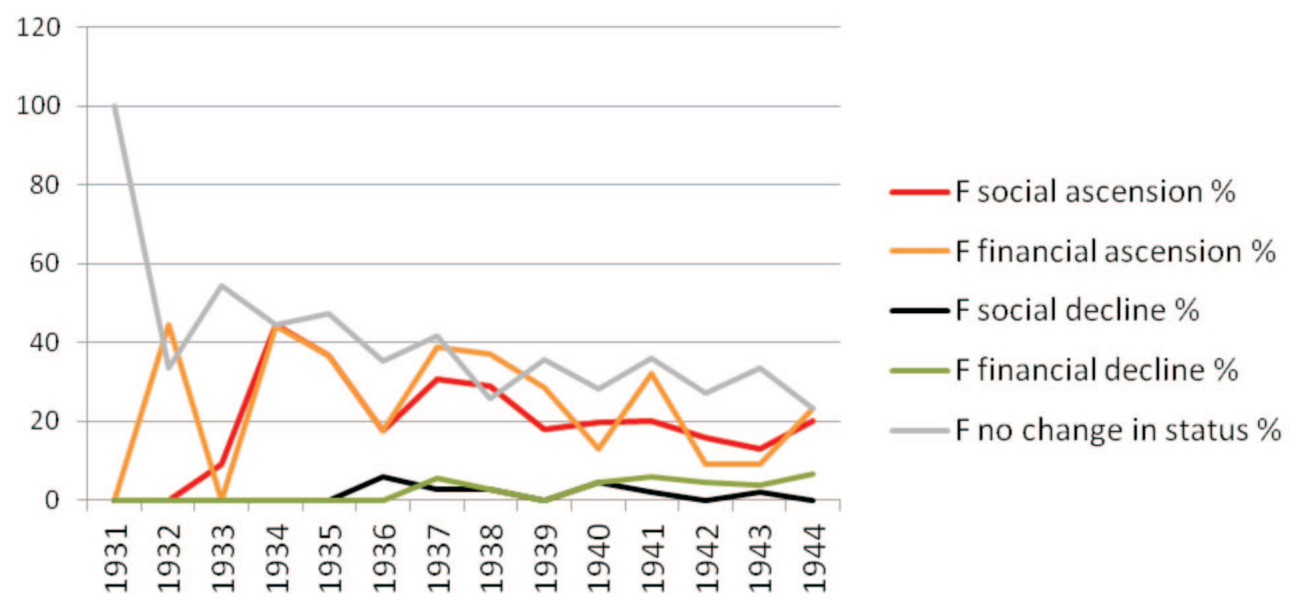

